\title{
AID FOR AFRICA AS ONE OF THE ACTIVITIES CARRIED OUT BY POLISH NGOS: LEGAL AND SOCIOLOGICAL APPROACH
}

\section{Marek Stych}

Pedagogical University the National Education Commission in Krakow, Institute of Law and Economics, Krakow, Poland https://orcid.org/0000-0003-4359-1085

\section{Beata Pawlica}

Pedagogical University the National Education Commission in Krakow, Institute of Political Sciences and Administration, Krakow, Poland https://orcid.org/0000-0002-2941-7470

\section{Malgorzata Kmak}

Pedagogical University the National Education Commission in Krakow, Institute of Political Sciences and Administration, Krakow, Poland https://orcid.org/0000-0002-2285-5793

OMESTE

JEL Category: F35, H12

\begin{abstract}
This article tackles the issue of aid for African states. Africa is one of the poorest continents, with many people living on the verge of poverty and suffering from malnutrition or famine. Hence, the humanitarian aid provided to the people of this continent is of particular importance. In Poland, such aid activities undertake entities defined in the Polish legal system as non-governmental organizations (NGOs). NGOs also conduct many other kinds of activities. The Act on public benefit and volunteer work is an example of creating legal mechanisms for the functioning of civil society in the legal system to provide international aid to those it needs. Assisting other societies is important for modern civil society the same as political or economic cooperations are. The role of NGOs operating in health protection, education, or entrepreneurship areas is crucially important. The authors of this paper discuss the issue of the said aid provided by selected Polish NGOs. The article aims to determine the extent and scope of the assistance to African countries provided by the NGOs, based on the respondents' experiences, whether such Address of the corresponding author: assistance is necessary, and what form it should take.
\end{abstract}


Keywords: humanitarian aid, aid for African countries, development assistance, non-governmental organizations.

\section{INTRODUCTION}

Famine and poverty that affect many people on our planet are considered the overriding problems of the contemporary world. Africa continent has the lowest GDP per capita, ranging from $\$ 208$ in Burundi to $\$ 9,238$ in Equatorial Guinea (as of December 2019) (Trading Economics, 2020). At the same time, many African countries are affected by epidemics of malaria and other diseases such as AIDS or COVID-19.

As a result, Africa is the poorest continent, with millions of its inhabitants suffering from malnutrition or famine (More than 1.2 billion people worldwide live on less than $\$ 1$ a day; another billion people live on $\$ 2$ a day; 4 billion people live on less than $\$ 4$ a day). What is more, civil wars and various armed conflicts are still ongoing in several African countries. Military operations have worsened the already difficult situation of the people living in those areas. Therefore, the aid provided to the people of Africa is of particular importance and has a humanitarian character.

In Poland, such aid activities carry out entities defined in the Polish legal system as nongovernmental organizations (NGOs). They have a well-established position among all entities conducting similar activities in this country. Nowadays, we observe their activity in numerous areas, including providing aid to communities inhabiting the African continent. We perceive these organizations as a manifestation of civil society, which undertakes bottom-up and voluntary actions for building the common good by combining individual interests into a jointly articulated and pursued need to help other societies and groups, regardless of cultural and religious differences. NGOs also conduct many other kinds of activities. The Act on public benefit and volunteer work is an example of creating legal mechanisms for the functioning of civil society in the legal system to provide international aid to those in need is (Act, 2003). For modern civil society, assisting others is crucial as political or economic cooperation. The role of NGOs operating in various areas such as health protection, education, or entrepreneurship is crucially important.
A separate group of organizations in the Polish legal system is called public benefit organizations (PBOs). A PBO is an NGO that has been given a public benefit status by a court decision and entered in the National Court Register. Such organizations have been operating in Poland since the $29^{\text {th }}$ of June 2003, when the Act entered into force. Its provisions introduced special types of organizations performing public benefit tasks.

The mass media supports the Polish PBOs' aids activities. Their role is to exercise the so-called informal control. It makes it easier for the public to gain information about the finances of organizations and institutions performing public tasks or reports on public funds allocated for overseas humanitarian aid.

The organizations mentioned above constitute the so-called non-governmental sector, which is relatively highly diversified, both in terms of aid tasks performed and organizational forms (In 2018 , there were over 26,000 foundations and 117,000 associations operating in Poland).

There are several reasons why various forms of assistance are provided to African countries, e.g., diseases, armed conflicts, natural disasters, crop failure, or famine.

Aid benefits in contemporary modern societies have several dimensions:

- organizational - aid is aimed at economic development and stimulation of entrepreneurship.

- financial - aid is provided as a money transfer.

- educational - the public is informed about the need to provide aid.

- cultural - aid is provided to culturally or religiously different societies.

\section{METHODOLOGY}

This article aims to answer the following questions:

What are the extents and scope of the NGOs' assistance provided to African countries?

What do the respondents think about the aid for African states, and what forms should provide? 
To answer the above questions, the authors applied the desk research together with the dogmatic-legal method. This method analyses relevant literature, legal acts, and documents related to various forms of assistance provided to Africa.

\section{WHAT IS DEVELOPMENT ASSISTANCE?}

Embarking on an analysis of the discussed matter one should first introduce concepts functioning at the EU and the national level (Paterek, 2013). The Lisbon Treaty of 2007 is of fundamental importance in determining the directions of development assistance. The document points to development assistance aimed at reducing poverty in developing countries. The document points to development assistance aimed at reducing poverty in developing countries. Development assistance should be provided in line with the principles and objectives of the EU's external actions. According to the definition adopted by the OECD Development Assistance Committee (DAC), Official Development Assistance (ODA) includes donations and loans given to developing countries by official government organizations of rich countries or international organizations to support the economic development and prosperity of the former (Sobotka, 2009). However, for a loan to be considered development assistance, at least $25 \%$ of its amount should come from a donation. Such assistance can be provided in two forms. Firstly, through international institutions (the so-called multilateral assistance); secondly, directly by Polish institutions, including NGOs (the so-called bilateral assistance) (Świerczyńska, 2012).

When it comes to Polish regulations, development cooperation is provided for in the Act of 16 September 2011 on development cooperation (Act, 2011). The Polish legislator made the right decision to define the two fundamental notions which, according to the authors of the paper, are of crucial importance for aid activities conducted in Africa. Those are:

development assistance - promoting and supporting the development of democracy and civil society, including parliamentary system development, good governance, and observance of human rights; supporting sustainable social and economic development, undertaking actions aimed at reducing poverty and improving the health condition of the population, and raising the level of education and professional qualifications of the population,

- humanitarian aid - providing assistance, care, and protection to people who have been affected by armed conflicts, natural disasters (IRIN, 2012), or other humanitarian crises caused by nature or man (Stopka, 2012).

It seems reasonable to conclude that in the Polish legal and administrative framework development cooperation can be treated as a certain sphere of educational activity aimed at raising awareness and understanding of global problems and interdependencies existing between states. Therefore, it is possible to introduce the concept of "global education" into public administration (Article 2 Paragraph 2 of the cited Act). In this respect, one should emphasize the coherence of Polish regulations, as they allow entities referred to as PBOs to participate in development cooperation, which the authors assess positively. The importance of development assistance at the national level is evidenced by the fact that Poland only in 2011 spent approximately $\$ 417$ million on it, ranking $39^{\text {th }}$ in the $\mathrm{HDI}^{1}$ (Based on data from World Development Indicators (2012) of the World Bank).

\section{NGO AND PBO - ADMINISTRATIVE-LEGAL DEFINITION PROBLEM}

The NGO sector in Poland is very diverse and encompasses entities operating in various legal forms. They are neither state bodies nor units supervised by public administration (neither the central government nor local government), and their activity is not profit-oriented. In the Polish legal system, they are described as the "third sector" (Blicharz \& Zacharko, 2017), so they can be distinguished from the public and the private sectors.

\footnotetext{
${ }^{1}$ Based on (World Development Indicators 2012)
} 
The definition of an NGO can be found in the Act on public benefit and volunteer work (Gawlik, 2017, pp. 6-8). It is a legal definition, which is referred to also in other legal acts. According to the provisions of the said Act (Article 3 Paragraph 2), NGOs include:

- entities other than public finance sector units, within the meaning of the Public Finance Act,

- entities that are not profit-oriented,

- entities that have a legal person status, or organizational units without legal personality which have been granted legal capacity under separate provisions.

Therefore, NGOs include entities :

- have a legal personality (Political parties, trade unions, employers' organizations, professional self-government organizations, foundations, registered associations, church legal entities), and

- do not have a legal personality (for example, unregistered associations, university student organizations, country housewives' clubs).

Having conducted a linguistic interpretation of the above provision, one may assume that there are two criteria to be considered when deciding whether a given entity is or is not an NGO:

- the entity must not be part of the public finance sector,

- the entity must conduct activities of noncommercial nature.

The Polish legislator allows a certain category of NGOs to apply for the PBO status and enjoy the rights reserved only for such NGOs in the Act on public benefit and volunteer work (Chrzczonowicz, 2015, pp. 9-18). An analysis of the Act's provisions allows one to conclude that political parties and foundations created by them, trade unions, employers' organizations, and professional selfgovernment organizations fit in the definition of an NGO. However, they cannot obtain the PBO status because the scope of the tasks they perform does not fall under the category of public benefit activities.

The status registration of such organizations is kept in the National Court Register, which was created according to Article 1 of the Act of 20 August 1997 on the National Court Register (Act, 2021). The Register consists of three parts:

- The register of entrepreneurs.
The register of associations, other social and professional organizations, foundations, and public health care institutions - this part contains information on whether a given organization has fulfilled the conditions specified in the Act on public benefit and volunteer work.

- The register of insolvent debtors.

\section{PBOs' TASKS}

Public benefit activity, which is provided for in Article 4 of the Act on public benefit and volunteer work, covers the so-called public tasks, that is the tasks aimed at meeting the needs of communities or societies. An analysis of the statistical data available on the websites of the surveyed organizations makes it possible to list the tasks carried out by those PBOs in the years 2018-2020:

1. Provision of social assistance for African communities, e.g.:

- sponsoring meals for children in Madagascar,

- the program „Nasiona na zasiew” [Seeds for sowing] in Madagascar,

- the program "Uprawa i hodowla" [Cultivation and breeding] in Nairobi, Kenya,

- the program „Jadalnia dla przedszkola” [Canteen for kindergarteners] in Maganzo, Tanzania,

- the program "Stołówka dla szkoły” [Canteen for schoolchildren] in Chamuka, Zambia,

2. Raising awareness of both Polish and African societies, e.g.:

- an educational project encouraging charity and volunteering, Poland,

- education of children, Madagascar,

- an educational program for the refugees from Eritrea, Sudan, and South Sudan in Cairo, Egypt,

3. Protection and promotion of health - especially important for small ethnic communities in Africa, e.g.:

- a health center construction project, Mbaikoro, Chad,

- a project of bathrooms for a health center, Hanyigba, Togo,

- a health clinic construction project, Dimako, Cameroon, 
- the purchase of oxygen concentrators for a hospital in Antsirabe, Madagascar,

- the purchase of a barge for transporting patients in Berevo, Madagascar,

- assistance for a hospital in Antsirabe during the COVID-19 epidemic, Madagascar,

4. Activities for the benefit of the disabled, e.g.:

- aid for the blind in Ngaoundaye, Central African Republic,

- the construction of a well for lepers, Mampikony, Madagascar,

5. Supporting economic development and entrepreneurship, e.g.:

- financing an extension of the school farm in Chamuka, Zambia,

- the purchase of a harness for an educational farm in Anivorano, Madagascar,

- financing agricultural equipment for the poor in Kiabakari, Tanzania,

- the purchase of a tractor for an educational farm in Anivorano, Madagascar,

- the installation of a cold store for a farm in Kasisi, Zambia,

- the opening of a store in Kimbanseke in Kinshasa, Congo,

6. Development assistance in the field of science, education, and upbringing - financing e.g.:

- textbooks for a school in Kiabakari, Tanzania,

- a nursery for 50 children in the capital of Tanzania,

- aid for a street children center in Antananarivo, Madagascar,

7. Humanitarian aid for victims of catastrophes, natural disasters, and armed conflicts financing, e.g.:

- the purchase of rice for flood victims, Madagascar,

- actions aimed at combating a measles epidemic in Mampikony and Antsirabe, Madagascar.

The above list of activities undertaken by the surveyed organizations is a result of the analysis of the data available on their websites. The analysis' outcomes make it possible to conclude that the scope of these activities is relatively broad, and the legislator has given these organizations a lot of freedom in the area of assistance activities.

When it comes to the sources of financing, the provisions of the analyzed act allow PBOs to obtain additional funds only to expand the scale of activities undertaken. These sources include, for example:

1. Tax exemptions, including corporate income tax, real estate tax, stamp duty, and court fees, and civil law transactions tax,

2. Preferences in acquiring the right to use real estate owned by the State Treasury.

3. The right to free publicity on public radio and television.

The Act on public benefit and volunteer work is only a regulatory framework for the functioning of Polish aid organizations. The provisions of the Act are supplemented by specific regulations on the organizational form of such entities, which include:

- the Act of 7 April 1989 on associations (Act, 1989),

- the Act of 6 April 1984 on foundations (Law, 1984),

- the Civil Code of 23 of April 1964 (Civil Code, 1964).

The final shape of each PBO is stipulated in its statute. The authors analyzed certain regulatory aspects of the five selected NGOs. The range of tasks performed by such organizations is considerably wide, but only the regulations concerning the goals and tasks related to helping African states have been analyzed in the paper. Moving on to the aforementioned statutes, further analysis will cover selected PBOs carrying out aid activities for Africa. The selected organizations include:

\section{Polish Foundation for Africa}

The area of its operation is provided for in Paragraph 6 of the statute: "The Foundation operates in the territory of the Republic of Poland and abroad". This enables the organization to provide aid to African countries. The goal of the Foundation, set in Paragraph 11 , is to conduct activities aimed at improving the material situation and quality of life of the poorest African communities, particularly in areas such as:

- social assistance,

- charity,

- promotion and protection of health, 
- support for the disabled,

- economic development, including the stimulation of entrepreneurship,

- science, education, higher education, and upbringing,

- support for children and teenagers,

- assistance for victims of catastrophes, natural disasters, armed conflicts, and wars.

The actual actions undertaken by the Foundation include non-profit public benefit activities such as:

- providing financial and material support for foreign institutions and institutions engaged in activities aimed at protecting the health of the inhabitants of Africa and improving their living conditions,

- acquiring, managing, and distributing funds and financial and non-financial donations for those in need,

- conducting and supporting activities aimed at improving the living, material, and social situation of the inhabitants of Africa,

- providing grants and scholarships to the inhabitants of Africa,

- organizing aid trips,

- organizing educational and cultural events aimed at informing about the aid for Africa,

- assisting victims of catastrophes, natural disasters, and armed conflicts in Africa.

\section{Polish Medical Mission.}

An analysis of the organization's statute shows that the area of its activity is like the previously examined organization. Its goals and actual activities resemble the ones of the "Polish Foundation for Africa".

\section{Polish Humanitarian Action.}

The goal of this foundation is to organize and provide humanitarian, development, and charitable assistance which is socially useful and educational. Having analyzed the organization's statute, one can conclude that the scope of its tasks is characterized by a greater degree of generality. One difference is their right to conduct permanent and temporary aid missions.

4. Foundation Polish Center for International Aid.

According to Paragraph 1 Subparagraph 3 of its statute, the Foundation has the right to undertake activities outside the territory of the Republic of Poland. The following Paragraph stipulates the goals of the Foundation, which include:
- supporting people affected by humanitarian crises, civil wars, and natural disasters abroad,

- providing humanitarian aid,

- providing development, technical, educational, and health assistance,

providing support for refugees, internally displaced persons, and other groups with humanitarian needs.

According to Paragraph 3 , these goals are to be achieved through:

- collecting, preparing, and dispatching humanitarian and development aid abroad, including medicinal products and medical devices.

- organizing mass events, concerts, cultural and artistic events.

- publishing activities as well as film, television, and multimedia production.

5. Caritas Poland reactivated on 10 October 1990.

This entity is an example of the so-called Church legal entity. Therefore, its charity goals draw from Catholic values and stem from "the service of mercy". According to the provisions of Caritas's statute, the organization's tasks include:

- analyzing the causes and size of human poverty, and developing programs and prevention measures to combat it effectively,

- conducting charity and care activities,

- conducting activities for the benefit of people in need: refugees, victims of natural disasters, epidemics, and armed conflicts,

- providing or organizing non-financial assistance for social groups,

- organizing ad hoc and development assistance abroad,

- organizing humanitarian aid transports.

The above analysis of the statutes allows the following conclusions to be drawn:

- the scope of the assistance activities the examined organizations conduct is wide,

- their tasks are thoroughly described in these acts, which is good,

the list of their sources of financing is nonexhaustive. 


\section{OWN RESEARCH - EVALUATION OF THE NGOS' ACTIVITIES AIMED AT HELPING AFRICA}

Empirical research for this article was conducted among randomly selected respondents. The research was carried out in the Silesian urban area (the largest in Poland), which consists of 19 municipal units. 1,500 respondents - adult inhabitants of the said area took part in the survey. 850 of them were women and 650 of them were men.

The first question in the questionnaire was "What do you understand by the term non-governmental organization and what do you associate with it?" $35 \%$ of the respondents did not have any specific associations. Such answers were given more often by the men ( $62 \%$ of the respondents) and the respondents with secondary education (68\%). The remaining respondents associated NGOs with helping people (22\%), independence and autonomy (23\%), fundraising ( $27 \%)$, and voluntary work, social work, and non-profit activities (4\%). Moreover, some of the respondents associated the term NGO with specific organizations, e.g., the Polish Red Cross, Caritas, Volunteer Fire Brigade, and farmers' wives' associations $(3 \%$ of the respondents). The respondents most often perceived an NGO as an organization whose primary task is to raise money for specific, socially important goals and to help those in need.

The next question was about the activities undertaken by NGOs. Most of the respondents associated them with activities related to helping people in need - the poor, homeless, disabled, sick ( $86 \%$ of the respondents), with fundraising for socially important goals $(78 \%)$, with caring for animals and the environment (70\%). The respondents seem to have been right because such activity is typical for non-profit organizations.

A broader understanding of the scope of activities undertaken by such organizations is more widespread among the respondents aged 18-35 (64\%), with higher education (82\%). Undoubtedly, this group has greater knowledge of the diversity of the non-governmental sector and the competencies of NGOs.

The respondents declared a significant level of trust in various forms of NGOs. The survey revealed that the respondents placed their trust most often in foundations (66\%) and associations $(60 \%)$. The trust in various NGOs increases with the level of the respondents' education. The respondents with higher education trusted NGOs slightly more often (58\%). At the same time, $28 \%$ of the respondents did not trust foundations and $31 \%$ of them did not trust associations.

One of the NGOs' goals is to carry out aid activities for the benefit of the inhabitants of many African countries. The respondents advocated such actions. Most of them (74\%) were in favor of providing such assistance, $64 \%$ of whom were women, and $84 \%$ the respondents with higher education. Interestingly, $46 \%$ of the respondents with secondary education did not approve of the activities and resources of Polish NGOs being provided to the inhabitants of Africa.

The next question was about the forms of aid activities carried out by NGOs for African communities. $58 \%$ of the respondents pointed to educational activities in African countries, whereas $23 \%$ of them pointed to activities in health protection. The smallest number of the respondents pointed to the development of entrepreneurship in these countries (12\%). Interestingly, this group included mainly the respondents with higher education (81\%) and aged 18-35 (63\%). The respondents with higher education indicated that NGOs assisting African countries should focus on educational activities. In their opinion, such activities could positively change the mentality of the people living in Africa and lead to the development of entrepreneurship. Only $7 \%$ of the respondents in this category pointed to the financial aspect of NGOs' activities. In their view, donating funds to the Africans in need would improve their lives.

NGOs often help the inhabitants of Africa in need through the institutions of countries interested in this type of support. Therefore, it was important to ask the respondents about their opinion in this respect. $48 \%$ of the respondents (including $62 \%$ of the women) stated that African countries properly manage the external aid provided to them. $52 \%$ of the respondents had a different opinion (including $72 \%$ of the men).

One of the ways of helping Africans is also admitting immigrants. The respondents were asked about this form of help the survey revealed that the respondents aged 18-35 showed a 
reluctant attitude towards admitting immigrants (62\%). $48 \%$ of the respondents aged over 51 were willing to accept this form of support for migrants from Africa. In this age category, it was the women who approved of this idea more often $(64 \%$ of the female respondents).

\section{CONCLUSIONS}

Summing up the theoretical and empirical analysis of the discussed issue, development assistance is aptly perceived as a humanitarian duty of civil societies. However, it should be implemented skillfully by all interested parties. Well-organized aid leads to building positive relations between Poland and African countries based on partnership and diplomatic contacts.

However, the assistance provided to Africa should not at the same time hinder its development. Transferring money or shipping non-financial aid to Africa impedes or prevents the development of communities to some extent. From the economic point of view, it can be said to block the development of local markets. At the same time, providing financial support for Africa is in some cases accompanied by corruption, which means the funds do not go to the ones who need them.
For instance, in one of their reports Transparency International has classified African countries, especially the ones in the sub-Saharan region, as highly affected by corruption. This finds a particularly negative reflection in health care. For example, there are problems with counterfeit PCR screening tests and drugs, overcharging for medical care, or unfair distribution of food aid. The report points to the following countries:

- Republic of South Africa - an audit of expenditure on combating the Covid-19 epidemic has revealed cases of overcharging, fraud, and corruption.

- Nigeria - state drug distribution frauds.

- Zimbabwe - in some regions, the distribution of food and humanitarian aid is a privilege of the ruling party supporters.

The disclosure of these irregularities does not mean that the various forms of aid for Africa should be abandoned. The EU and developed countries should not mix politics with charity and therefore continue to provide development assistance for that continent.

All in all, the authors believe that Africa should be helped reasonably - its development should not be hindered but, at the same time, the number of possible irregularities should be limited.

\section{WORKS CITED}

Act. (1989, 04 7). Poland Law on associations - Parliamentary Act April 7, 1989. Retrieved from socioeco.org: https://base.socioeco.org/docs/poland_law_on_associations.pdf

Act. (2003, 04 24). The Act Of 24 April 2003 On The Activities Of Public Benefit And About Volunteering, item 1057. Retrieved from https://www.global-regulation.com/translation/poland/2985965/theact-of-24-april-2003-on-the-activities-of-public-benefit-and-about-volunteering.html

Act. (2011, 09 16). Development Cooperation Act. Retrieved from GOV.PL: https://www.gov.pl/attachment/0d4493f7-2d7a-470a-8925-72a0a0ef8294

Act. (2021). Act of 20 August 1997 on the National Court Register, Consolidated text. Journal Of Laws of 2021 , item 112

Blicharz, J., \& Zacharko, L. (2017). Trzeci sektor i ekonomia społeczna. Wroclaw: Uniwersytet Wroclawski.

Chrzczonowicz, M. (2015, 11 9). Organizacje pozytku publicznego. Uzyskanie statusu OPP, przywileje, obowiązki, kontrola. Retrieved from api.ngo.pl: https://api.ngo.pl/media/get/113421/3w-oppfragment.pdf

Civil Code. (1964, 04 23). Civil Code. Journal of Laws Dz.U., item 121.

Gawlik, R. (2017, 01 05). A commentary to the Act of 24 April 2003 on public benefit and volunteer work. Retrieved

from

City

Hall

in

Przemysl: 
https://przemysl.pl/download/attachment/57392/prezentnik-po-ustawie-o-dzialalnosci-dobrykupublic-io-wolontariacie.pdf

IRIN. (2012). Czy Meles Zenawi zdolal zapewnic Etiopii bezpieczenstwo zywnosciowe? Pomoc Rozwojowa, 30-31. Retrieved from https://pcpm.org.pl/uploads/Pomoc\%20Rozwojowa/PomocRozwojowa_2.pdf

Law. (1984, 04 06). Law on Foundations. Retrieved from Legislationline: https://www.legislationline.org/documents/id/4592

Paterek, A. (2013). Development aid as an instrument of Polish foreign policy in the second decade of the 21st century - challenges and opportunities. Krakowskie Studia Prawnicze(4), 208-215. Retrieved from https://repozytorium.ka.edu.pl/bitstream/handle/11315/23133/PATEREK_Pomoc_rozwojowa_j ako_instrument_polskiej_2013.pdf?sequence=1\&isAllowed=y

Sobotka, B. (2009). Efektywnosc pomocy rozwojowej /Effectiveness of the development aid. Annales Universitatis Mariae Curie-Skłodowska Lublin - Polonia, Politologia, XVI, 163-177. Retrieved from

https://www.researchgate.net/publication/330288912_Efektywnosc_pomocy_rozwojowejEffect iveness_of_the_development_aid

Stopka, P. (2012). Jemen - niedokonczona rewolucja. Pomoc Rozwojowa(2), 14-15. Retrieved from https://pcpm.org.pl/uploads/Pomoc\%20Rozwojowa/PomocRozwojowa_2.pdf

Świerczyńska, U. (2012). Transfery finansowe jako narzędzie międzynarodowej pomocy humanitarnej. Pomoc Rozwojowa, 22-23. $\quad$ Retrieved from https://pcpm.org.pl/uploads/Pomoc\%20Rozwojowa/PomocRozwojowa_2.pdf

Trading Economics. (2020, 12 12). PKB per capita - Lista krajow - Afrika. Retrieved from Trading Economics: https://pl.tradingeconomics.com/country-list/gdp-per-capita?continent=africa

World Development Indicators 2012. (2012). Retrieved from World Bank Group Open Knowledge Repository: https://openknowledge.worldbank.org/handle/10986/6014

Received for publication:

Revision received:

Accepted for publication:
13.11.2021

18.11 .2021

06.01 .2022

\section{How to cite this article?}

Style - APA Sixth Edition:

Stych, M., Pawlica, B., \& Kmak, M. (2022, 01 15). Aid for Africa as one of the activities carried out by Polish NGOs: Legal and sociological approach. (Z. Cekerevac, Ed.) MEST Journal, 10(1), $72-$ 81. doi:10.12709/mest.10.10.01.09

Style - Chicago Sixteenth Edition:

Stych, Marek, Beata Pawlica, and Malgorzata Kmak. 2022. "Aid for Africa as one of the activities carried out by Polish NGOs: Legal and sociological approach." Edited by Zoran Cekerevac. MEST Journal (MESTE) 10 (1): 72-81. doi:10.12709/mest.10.10.01.09. 
Style - GOST Name Sort:

Stych Marek, Pawlica Beata and Kmak Malgorzata Aid for Africa as one of the activities carried out by Polish NGOs: Legal and sociological approach [Journal] // MEST Journal / ed. Cekerevac Zoran. Belgrade - Toronto : MESTE, 01 15, 2022. - 1 : Vol. 10. - pp. 72-81.

Style - Harvard Anglia:

Stych, M., Pawlica, B. \& Kmak, M., 2022. Aid for Africa as one of the activities carried out by Polish NGOs: Legal and sociological approach. MEST Journal, 15 01, 10(1), pp. 72-81.

Style - ISO 690 Numerical Reference:

Aid for Africa as one of the activities carried out by Polish NGOs: Legal and sociological approach. Stych, Marek, Pawlica, Beata and Kmak, Malgorzata. [ed.] Zoran Cekerevac. 1, Belgrade - Toronto : MESTE, 01 15, 2022, MEST Journal, Vol. 10, pp. 72-81. 